\title{
Experience of Post-ICU Syndrome in Critical Disease Survivors
}

Ángela María Henao-Castaño

出ttps://orcid.org/0000-0003-4203-0016. Universidad Nacional de Colombia, Colombia. angmhenaocas@unal.edu.co

Nathaly Rivera-Romero

https://orcid.org/o0oo-0002-3758-8798. Universidad Nacional de Colombia, Colombia. nriverar@unal.edu.co

Heidi Paola Ospina Garzón

https://orcid.org/0000-0002-9802-7628. Hospital Federico Lleras Acosta, Colombia. hpospina@ucundinamarca.edu.co

Received: 17/03/2021

Sent to peers: 02/09/2021 Approved by peers: 07/10/2021

Accepted: 04/11/2021

\section{DOI: 10.5294/aqui.2022.22.1.6}

To reference this article / Para citar este artículo / Para citar este artigo Henao-Castaño AM, Rivera-Romero N, Ospina HP. Experience of Post-ICU Syndrome in Critical Disease Survivors. Aquichan. 2022;22(1):e2216. DOI: https://doi. org/10.5294/aqui.2022.22.1.6 
Theme: Evidence-based practice.

Contribution to the discipline: Post ICU syndrome is characterized by physical, cognitive, and emotional problems in the medium and long term after discharge. Considering the prevalence of these alterations, and their impact on people and even their families, understanding the experience of critical illness survivors after ICU discharge will make it possible to propose interventions that mitigate these symptoms, include this phenomenon in the training of personnel working in these units, and provide research tools to justify early symptom detection, mitigation, and rehabilitation programs that allow the patient to recover altered functions or minimize their impact. 


\section{Abstract}

Introduction: Surviving Intensive Care Unit (ICU) brings positive and negative feelings, depending on each person's experience. Likewise, some patients may present with negative mental and physical consequences after discharge, causing a very complex stay at home. Aim: To understand the experience of critical illness survivors after three months of ICU discharge. Methods: Hermeneutical phenomenological study using in-depth interviews with 15 adult participants after three months of ICU discharge. Data analysis was made considering Cohen, Kahn, and Steeves' procedures. Results: Phenomenological analysis revealed three existential themes: Changes in memory and mood, Changes in day-to-day life, and My body after ICU. Conclusion: Surviving ICU brings with it positive aspects such as winning a battle against death. However, psychological, emotional, and physical consequences after discharge turn it into an exhausting experience.

\section{Keywords (Source DeCS)}

Critical illness; critical care; qualitative research; patient; survivors. 


\section{Experiencia del síndrome post-UCl en supervivientes de enfermedades críticas}

\section{Resumen}

Introducción: sobrevivir a la Unidad de Cuidados Intensivos (UCI) trae sentimientos positivos y negativos, dependiendo de la experiencia de cada persona. Asimismo, algunos pacientes pueden presentar consecuencias físicas y mentales negativas tras el alta, lo que ocasiona una estadía en casa muy compleja. Objetivo: comprender la experiencia de los sobrevivientes de enfermedades críticas después de tres meses del alta de la UCl. Métodos: estudio fenomenológico hermenéutico mediante entrevistas a profundidad a 15 participantes adultos después de tres meses del alta de la UCl. El análisis de datos se realizó con base en los procedimientos de Cohen, Kahn y Steeves. Resultados: el análisis fenomenológico reveló tres temas existenciales: Cambios en la memoria y el estado de ánimo, Cambios en la vida cotidiana y Mi cuerpo después de la UCl. Conclusión: sobrevivir en la $\mathrm{UCl}$ trae consigo aspectos positivos como ganarle una batalla a la muerte; sin embargo, las consecuencias psicológicas, emocionales y físicas tras el alta convierten todo esto en una experiencia agotadora.

Palabras clave (Fuente: DeCS)

Enfermedad crítica; cuidados críticos; investigación cualitativa; paciente; sobrevivientes. 


\section{Experiência da síndrome pós-UTI em sobreviventes de doenças críticas}

\section{Resumo}

Introdução: sobreviver à Unidade de Tratamento Intensivo (UTI) traz sentimentos positivos e negativos, dependendo da experiência de cada um. Além disso, alguns pacientes podem apresentar consequências físicas e mentais negativas após a alta, o que ocasiona um período complexo de repouso domiciliar. Objetivo: compreender a experiência dos sobreviventes de doenças críticas depois de três meses da alta da UTI. Materiais e métodos: estudo fenomenológico hermenêutico mediante entrevistas a profundidade com 15 participantes adultos depois de três meses de receberem alta da UTI. A análise de dados foi realizada com base nos procedimentos de Cohen, Kahn e Steeves. Resultados: a análise fenomenológica revelou três temas existenciais: "mudanças na memória e no humor", "mudanças na vida cotidiana" e "meu corpo depois da UTI". Conclusões: sobreviver à UTI traz consigo aspectos positivos como o sentimento de ter ganhado uma batalha contra a morte; contudo, as consequências psicológicas, emocionais e físicas após receber a alta tornam tudo isso uma experiência exaustiva.

\section{Palavras-chave (Fonte: DeCS)}

Estado terminal; cuidados críticos; pesquisa qualitativa; paciente; sobreviventes. 
Despite technology and medical and care advances, a typical experience in the intensive care unit (ICU) involves many patients leaving it. Consequently, discharge from the intensive care unit becomes a long road for many former patients. During hospitalization in the ICU, they are faced with isolation from their families, immobilization, sedation, painful procedures, and physical deconditioning that may persist one to five years after hospital discharge, resulting in motor problems and risk of falling and adversely affecting the quality of life (1). Other patients develop delirium, a consciousness alteration shown in disorganized cognition and perception; it varies from hours to days and prevents the information from being properly processed, stored, and remembered (2). It is also associated with poor prognosis for the patient (3), such as more extended hospital stay (4), high mortality rates $(5,6)$, readmission to ICU (7), cognitive decline (8), and long-term functional impairment (9); anxiety, depression (10), and other psychiatric symptoms in $17-47 \%$ of the cases (11).

The American Association for Critical Care defines Post Intensive Care Syndrome (PICS) as a set of new impairments that worsen physical and cognitive or mental health beyond ICU hospitalization (12). PICS considers the impact that the intensive care unit can have on the patients' lives after discharge and the manifestations experienced.

The first manifestation reported in the literature is generalized muscle weakness and poor mobility and signs and symptoms of myopathy due to critical illness; the triggers considered are malnutrition and sensory disorders (13). Alteration in sleep patterns is reported in a study in which some patients did not remember their stay in the ICU, for which amnesia is often cited as a consequence of sedating a mechanically ventilated patient (14). In one study, patients reported confused or disoriented memories and negative memories (20-45\%) related to pain, anguish, sleeping difficulties, noise, fear, and feeling of abandonment; $20 \%$ reported positive memories. At three months, the experience in the ICU was characterized by anxiety and posttraumatic stress disorder (15). In qualitative studies, participants describe sleeping difficulties, expressing the need for a night of normal sleep and how nightmares torment them after hospital discharge (16).

Thus, this research aims to understand the experience of critical illness survivors three months after ICU discharge. This study will allow the nursing staff to understand patients' sequelae after discharge and thus develop strategies that reduce problems with timely integration into daily life.

\section{Materials and methods}

This qualitative research is of a hermeneutical phenomenological type. Qualitative research helps to understand social phenomena, 
emphasizing participants' experiences and points of view (17). The phenomenological approach is the deep understanding of a phenomenon from the experience until it reaches its essence (18).

The study was conducted in a twelve-bed ICU of a tertiary referral hospital in a city in Colombia. The inclusion criteria were as follows: adults with physical and mental conditions, after ICU hospitalization, willing to be interviewed and participate in the study. Records were available to locate each participant.

After explaining the aim and method to each participant, they gave their verbal consent. No financial or other remuneration was offered, with no coercion by the researcher, who announced that the interview would end when they said so. Interviews were conducted by a single interviewer from the nursing staff affiliated with the ICU from which participants were discharged. The interviews were carried out without complications, protecting privacy and confidentiality by avoiding proper names and giving a number to each interview.

The sampling included fifteen volunteers who met the selection criteria. The participants' contact details were provided by the discharge registry of the last three months of the ICU in which the study was conducted. In-depth interviews were conducted to collect the information, asking a central question about their experience. Questions: How was your experience three months after ICU discharge? What changes have you experienced in your daily life? The interviews lasted 40 to 60 minutes, were recorded in magnetic medium, and conducted between October and November 2019. The participants were interviewed individually at their homes. In eight interviews, they were with a family member who did not participate in the interview. The participant's autonomy to end the interview at the time indicated was respected.

We analyzed data manually as recommended by Cohen, Kahn, and Steeves (16). First, the interview was transcribed to the end, without omitting any phrase or expression, then compared to the recording and finally saved on a computer. Then, each sentence was read line by line. The initial interpretation gave the general aspects, followed by coding, analysis, and transformation into significant data. Topics in another record were labeled with the interview number, page, and consecutive number to locate each interview. Their interpretation showed the participants' point of view and depth the researcher gave to each finding; it reflected reality but respected their individual expression. Then, the second interview was conducted, following the same process and order described above, until obtaining the theoretical saturation of the data, achieved with 15 participants.

The data analysis followed the three phases proposed by Van Manen. Phase I describes the experience three months after ICU discharge. In Phase II, the experience was interpreted by generating units of meaning and themes supported by the interviews and field notes; the themes were identified by two of the researchers. In Phase III, description and interpretation were combined, reflected 
in themes and their similarities, allowing an understanding of the phenomenon and the preparation of the text (19).

Two preliminary interviews were conducted to assess communication and interaction with the participant. Questions were also evaluated to identify those that produced enriching answers for later analysis. Experts reviewed all results and helped to estimate their relationship with the aim. The study has the institutional endorsement under the Declaration of Helsinki guidelines (20) and includes all ethical aspects to protect participants. Signing the written informed consent was requested to participate in the study and record the interviews, where the study objectives and methods were explicit. The interviewer had training for referring and counseling the interviewee in case of identifying alterations in their physical and mental health that require immediate attention.

\section{Results}

Fifteen people, including five women and ten men, participated in the study, with educational levels ranging from primary to secondary education. The youngest was 25 years old and the oldest 86 , and for thirteen of the participants, it was their first ICU hospitalization. Admission to the ICU was elective for one participant with a postoperative diagnosis of orthopedic surgery; the other 14 participants were admitted unplanned due to pneumonia (4), acute myocardial infarction (3), renal failure (4), and stroke (3). The average length of ICU stay was nine days, with mechanical ventilation. All interviews were held at home.

The ICU where the participants were hospitalized is a unit for different critical illness diagnoses. It is the most important referral center in the city. It has 12 independent patient cubicles and the care of an interdisciplinary group

\section{Changes in memory and mood}

For the participants, hospitalization in the ICU meant dramatic changes. Their stories revealed alterations in their mental functions, mainly in memory, mood, sleep cycle, and cognition.

Regarding memory, they had from occasional gaps that improved over time to significant alterations in working memory that needed the company of a family member for some activities:

\footnotetext{
"The first few days at home, I hardly remembered things. Now, thank God, I have recovered most of my memory because it was like losing it." E2

"I have noticed that my memory has decreased; in any case, having been there has been a complication because I feel that I would have been someone if I had not gone through that event." E4

"I have become forgetful; I forget to take my medication." E10
}

Most of the participants reported significant changes in their mood after the ICU. They had no desire to do anything, avoided contact 
with other people, and felt discouraged; symptoms such as anhedonia, sadness, and even anxiety were identified in the speech. Some of them experienced these effects just after discharge, but others continued with these symptoms even until the interview.

"Depressed, tired; there are days when I am very disheartened. I went out alone. I did not want to contact anyone; everyone annoyed me. I was very depressed, exhausted. I did not want to do anything with anyone. I did not want to go out. It seemed awkward to me." E15

"I feel discouraged. I do not feel like talking to anyone or listening to people, much less having long conversations. I used to talk a lot, and I liked learning about many things.

Now, I am not interested in anything." E8

"Depression. I just want to cry and run away. That's how I feel, and I don't know why." E13

Few participants reported disturbances in the sleep cycle, such as conciliation insomnia, waking up several times at night, and sleeping but no resting. This aspect is striking, given that sleep is essential to have physiological and emotional balance, especially after being hospitalized in the ICU.

"Some nights I don't sleep well; I can't fall asleep." E1

"I am sleepless, and I feel tired, like exhausted from not sleeping. The tranquility of sleeping goes away. I cannot sleep at night." E3

\section{Changes in day-to-day life}

During the interviews, patients described before and after ICU scenarios in their daily lives. They talked about physical alterations that made it difficult or impossible for them to perform some daily activities, including decreased independence, especially in activities outside the home. This topic highlighted the importance of physical therapy as a treatment for critical patients to mitigate short-term sequelae and keep their independence.

"I do all my shores by myself. Now I get tired after a long walk, but things at home are fine. If I go to a place with big crowds, I get tired. I do not do that kind of activity alone anymore." E17

"I was a little bit worried when I started feeling exhausted, but after a while, everything came back to normal." E7

Accompaniment became emotional support due to the participants' muscle fatigue when doing outdoor activities involving cognition such as money management. The impact on the degree of the person's independence went beyond muscular disorders, turning into emotional sequelae that affected social integration after admission to the ICU.

"I carry out daily life activities at home normally, although I feel exhausted. However, I have limited activities outside the house; now, my family always go with me." E3

"I require assistance to go shopping, and with money, however, I can do activities such as bathing or brushing my hair by myself." E11

"Now I am afraid of going out alone; I feel nervous and worried about that. I always look for someone to go out with me." E15 


\section{My body after the ICU}

Some patients reported changes in their bodies after their stay in the ICU. Voice changes were identified with some other physical alterations that made communication difficult. They also talked about changes in their weight and appearance caused by the orotracheal tube associated with mechanical ventilation and the routine laryngoscopy procedures performed in the ICU.

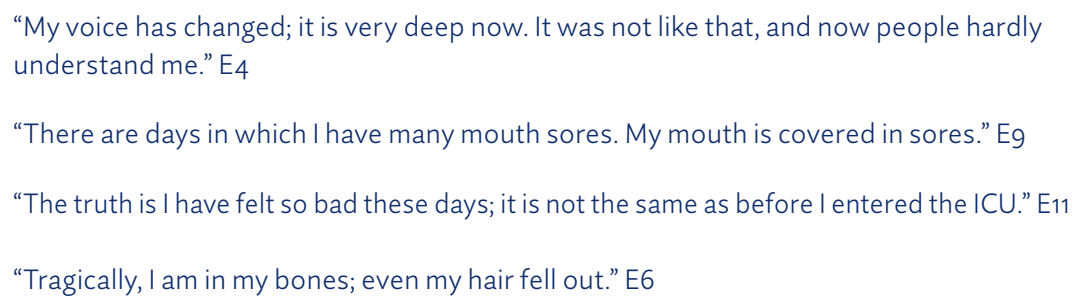

Likewise, they identified pain as a symptom that persisted after discharge. They emphasized the discomfort that it causes. Prolonged times in bed with a critical illness left a mark on the participants' skin of such a magnitude that muscle discomfort and pain were present even three months after ICU discharge.

"When I sit and then get up, my legs hurt, at the level of the hip." E4

"My back sores; I feel excruciating pain." E7

"Sometimes, I'm in pain." E12

\section{Discussion}

The results identified the meaning given to the experience of being an ICU survivor. However, despite recovering from a critical illness, they still present with psychological, cognitive, and physical disorders. These results are consistent with those provided by other studies in which survivors expressed psychological disorders (particularly depression), respiratory problems (abnormal spirometry), and moderate to severe dyspnea during daily life activities. Significant deterioration in the quality of life and functional capacity were also noted $(21,22)$. These aspects were recognized by the participants, remarking by their dependence on other family members to carry out life activities, such as managing money.

Studies one year after discharge report improvements in physical function, vitality, and social skills. However, these domains are also the least likely to recover in the common population, as they were more deeply affected by critical illnesses (23). The study participants were contacted three months after admission to the ICU; hence, the reported experiences should continue to be investigated much longer.

Alterations such as anxiety and depression in ICU survivors were higher than in the general population. Almost one-third of ICU survivors with delirium dealt with depression, anxiety, and post- 
traumatic stress and needed psychiatric help even one year after discharge (24). Another study reported poor quality of life after ICU discharge, showing a significant association with post-traumatic syndromes, anxiety, and depression (25).

Sleep disturbances are present in patients with the post-ICU syndrome. A study in ICU survivors showed that prolonged mechanical ventilation was related to fragmented sleep after discharge $(26,27)$. In some cases, sleep cycle distortions associated with mechanical ventilation finally improved six months after discharge.

Dependence on others for specific activities has been reported in studies with elderly ICU survivors. In these studies, the baseline functional state did not recover after one year, with a moderate to severe level of dependence (28). In another study, functional dependence initially increased but decreased one to three months after discharge. It affected the quality of life regarding mobility, personal care, habitual activities, pain, and anxiety/depression three months after ICU discharge (29).

Dependence occurs because ICU survivors do not feel safe. Priorities during their return home are focused on feeling comfortable, improving mobility, self-control, and self-care. Other essential goals are affirming personality, connecting with people, ensuring family well-being, restoring psychological and physical health, resuming previous roles and routines, and looking for new experiences (30).

In this way, it is vital to incorporate improvement strategies related to early detection of pain and delirium, favoring early mobility and conscious sedation management while preventing patients from reaching their maximum level of suffering. After discharge, the consequences of admission to the ICU were evaluated. Therefore, strategies with educational aids such as videos, simulation, and training in detection instruments must be developed for the interdisciplinary group that works in the ICU.

\section{Conclusions}

Surviving the intensive care unit has many advantages such as winning a battle against death. However, discharge's psychological, emotional, and physical consequences make this experience exhausting for patients and caregivers.

Knowing these experiences provides a research approach to propose interventions that mitigate these symptoms after ICU discharge. It makes it possible to demonstrate the need to include this phenomenon in the training of personnel working in these units and strengthen interdisciplinary work aimed both at patient care in the ICU and after discharge. Likewise, this paper calls for the early identification of symptoms to mitigate the consequences of ICU stay. 
Limitations: The participants expressed their experience only three months after ICU discharge. Nursing research should be conducted for patients after admission to the ICU at 6 and 12 months.

Conflict of interest: The authors declare no conflict of interest

\section{References}

1. Bemis-Dougherty AR, Smith JM. What Follows Survival of Critical Illness? Physical Therapists' Management of Patients With Post-Intensive Care Syndrome. Phys Ther. 2013 Feb;93(2):17985. DOI: https://doi.org/10.2522/ptj.20110429

2. Kotfis K, Marra A, Ely EW. ICU delirium - a diagnostic and therapeutic challenge in the intensive care unit. Anestezjol Intens Ter. 2018 Jun;50(2):160-7. DOI: https://doi.org/10.5603/ AIT.a2018.0011

3. Inouye SK, Rushing JT, Foreman MD, Palmer RM, Pompei P. Does delirium contribute to poor hospital outcomes? J Gen Intern Med. 1998 Mar;13(4):234-42. DOI: https://doi.org/10.1046/j.15251497.1998.00073.x

4. Jackson JC, Girard TD, Gordon SM, Thompson JL, Shintani AK, Thomason JWW, et al. Long-term Cognitive and Psychological Outcomes in the Awakening and Breathing Controlled Trial. Am J Respir Crit Care Med. 2010 Jul;182(2):183-91. DOI: https://doi. org/10.1164/rccm.200903-0442OC

5. Ouimet S, Kavanagh BP, Gottfried SB, Skrobik Y. Incidence, risk factors and consequences of ICU delirium. Intensive Care Med. 2007;33(1):66-73. DOI: https://doi.org/10.1007/s00134-0060399-8

6. Pisani MA, Kong SYJ, KasI SV, Murphy TE, Araujo KLB, Van Ness $\mathrm{PH}$. Days of Delirium Are Associated with 1-Year Mortality in an Older Intensive Care Unit Population. Am J Respir Crit Care Med. 2009 Dec;18o(11):1092-7. DOI: https://doi.org/10.1164/rccm.200904-0537OC

7. Witlox J, Eurelings LSM, de Jonghe JFM, Kalisvaart KJ, Eikelenboom P, van Gool WA. Delirium in Elderly Patients and the Risk of Postdischarge Mortality, Institutionalization, and Dementia. JAMA. 2010 Jul;304(4):443. DOI: https://doi.org/10.1001/ jama.2010.1013

8. Girard TD, Jackson JC, Pandharipande PP, Pun BT, Thompson $J$ L, Shintani AK, et al. Delirium as a predictor of long-term cognitive impairment in survivors of critical illness. Crit Care Med. 2010 Jul;38(7):1513-20. DOI: https://doi.org/10.1097/ CCM.obo13e3181e47be1

9. Brummel NE, Jackson JC, Pandharipande PP, Thompson JL, Shintani AK, Dittus RS, et al. Delirium in the ICU and Subsequent Long-Term Disability Among Survivors of Mechanical Ventilation. Crit Care Med. 2014 Feb;42(2):369-77. DOI: https:// doi.org/10.1097/ccm.obo13e3182a645bd

10. Midega TD, Oliveira HSB de, Fumis RRL. Satisfaction of family members of critically ill patients admitted to a public hospital intensive care unit and correlated factors. Rev Bras Ter Intensiva. 2019;31(2).

11. Wang S, Allen D, Perkins A, Monahan P, Khan S, Lasiter S, et al. Validation of a new clinical tool for post-intensive care syndrome. Am J Crit CARE. 2019 Jan;28(1):10-8. DOI: https://doi. org/10.4037/ajcc2019639

12. Needham DM, Davidson J, Cohen H, Hopkins RO, Weinert C, Wunsch $\mathrm{H}$, et al. Improving long-term outcomes after dis- charge from intensive care unit: Report from a stakeholders' conference. Crit Care Med. 2012;40(2):502-9. DOI: https://doi. org/10.1097/CCM.obo13e318232da75

13. Ferrante LE, Pisani MA, Murphy TE, Gahbauer EA, LeoSummers LS, Gill TM. Factors associated with functional recovery among older intensive care unit survivors. Am J Respir Crit Care Med. 2016;194(3):299-307. DOI: https://doi. org/10.1164/rccm.201506-1256OC

14. Henao Castaño ÁM, Gutiérrez SA, Trujillo JC. To be without sedation, is to know that one is alive. Invest educ enferm. 2010;28(1):23-31.

15. Chahraoui K, Laurent A, Bioy A, Quenot JP. Psychological experience of patients 3 months after a stay in the intensive care unit: A descriptive and qualitative study. J Crit Care [Internet]. 2015;30(3):599-605. DOI: https://doi.org/10.1016/j. jerc.2015.02.016

16. Altman MT, Knauert MP, Pisani MA. Sleep disturbance after hospitalization and critical illness: A systematic review. Ann Am Thorac Soc. 2017;14(9):1457-68. DOI: https://doi.org/10.1513/AnnalsATS.201702-148SR

17. Sinuff T, Cook DJ, Giacomini M. How qualitative research can contribute to research in the intensive care unit. J Crit Care. 2007;22(2):104-11. DOI: https://doi.org/10.1016/j. jcrc.2007.03.001

18. Frechette J, Bitzas V, Aubry M, Kilpatrick K, Lavoie-Tremblay M. Capturing Lived Experience: Methodological Considerations for Interpretive Phenomenological Inquiry. Int J Qual Methods. 2020;19:1-12. DOI: https://doi.org/10.1177/1609406920907254

19. Van Manen M. Phenomenology of Practice. California: Left Coast Press I; 2014.

20. Declaracion-Helsinki [Internet]. 2013. Available from: https:// www.wma.net/es/policies-post/declaracion-de-helsinki-de-la-amm-principios-eticos-para-las-investigaciones-medicas-en-seres-humanos/

21. Duarte PAD, Costa JB, Duarte ST, Taba S, Lordani CRF, Osaku $E F$, et al. Characteristics and outcomes of intensive care unit survivors: Experience of a multidisciplinary outpatient clinic in a teaching hospital. Clinics. 2017;72(12):764-72. DOI: https://doi. org/10.6061/clinics/2017(12)o8

22. Cuthbertson BH, Roughton S, Jenkinson D, MacLennan G, Vale L. Quality of life in the five years after intensive care: A cohort study. Crit Care. 2010;14(1):1-12. DOI: https://doi.org/10.1186/ cc8848

23. Gerth AMJ, Hatch RA, Young JD, Watkinson PJ. Changes in health-related quality of life after discharge from an intensive care unit: a systematic review. Anaesthesia. 2019;74(1):100-8. DOI: https://doi.org/10.1111/anae.14444

24. Ranzani OT, Zampieri FG, Park M, Salluh JIF. Long-term mortality after critical care: What is the starting point? Crit Care. 2013;17(5):1. DOI: https://doi.org/10.1186/cc13024 
25. Tripathy S, Acharya SP, Singh S, Patra S, Mishra BR, Kar N. Post traumatic stress symptoms, anxiety, and depression in patients after intensive care unit discharge- A longitudinal cohort study from a LMIC tertiary care centre. BMC Psychiatry. 2020;20(1):1-11. DOI: https://doi.org/10.1186/s12888-020-02632-x

26. Elías MN, Munro CL, Liang Z. Sleep Quality Associated With Motor Function Among Older Adult Survivors of Critical Illness. Nurs Res. 2020;69(4):322-8. DOI: https://doi.org/10.1097/ NNR.0000000000000418

27. El-Khatib MF, Esquinas AM. Sleep quality in survivors of critical illness: practical shortcomings unresolved. Sleep Breath. 2019;23(2):583-4. DOI: https://doi.org/10.1007/s11325-018-1719-2
28. Pintado MC, Villa P, Luján J, Trascasa M, Molina R, GonzálezGarcía N, et al. Mortality and functional status at one-year of follow-up in elderly patients with prolonged ICU stay. Med Intensiva. 2016;40(5):289-97. DOI: https://doi.org/10.1016/j.medine.2015.08.006

29. Heydon E, Wibrow B, Jacques A, Sonawane R, Anstey M. The needs of patients with post-intensive care syndrome: A prospective, observational study. Aust Crit Care. 2020;33(2):116-22. DOI: https://doi.org/10.1016/j.aucc.2019.04.002

30. Scheunemann LP, White JS, Prinjha S, Hamm ME, Girard TD, Skidmore ER, et al. Post-intensive care unit care: A qualitative analysis of patient priorities and implications for redesign. Ann Am Thorac Soc. 2020;17(2):221-8. DOI: https://doi.org/10.1513/AnnalsATS.201904-332OC 